\title{
Music as a complementary therapy in medical treatment
}

\author{
Samuel Halim
}

\begin{abstract}
Abstrak
Musik bukan saja merupakan sumber suara yang menyenangkan melainkan juga sumber kesembuhan. Musik sebagai terapi telah berkembang, didukung oleh banyak penelitian oleh para ahli di bidang musik, pendidikan dan kedokteran. Dampak terapi musik dapat dilihat pada berbagai kasus, yang menunjukkan pengaruh positif musik terhadap perbaikan perilaku, emosi, dan fisik manusia. Ada beberapa alasan menggunakan musik sebagai terapi yaitu musik sebagai audioanalgesik, pemfokus perhatian, dan lain-lain. Pengaruh musik untuk menolong berbagai pasien non-infeksi seperti Alzheimer, autisme, kanker dan lain-lain, akan dijelaskan disertai studi kasus dan penelitian tentang berbagai penyakit ini. Namun demikian terdapat kontroversi seputar hasil penelitian musik, karena itu penelitian lebih lanjut perlu dilakukan agar dicapai kesepakatan yang dapat mengukuhkan musik sebagai bentuk terapi yang dapat diterima dalam dunia medis masa kini maupun mendatang. (Med J Indones 2002; 11: 250-7)
\end{abstract}

\begin{abstract}
Music can act not only as a source of enjoyable sound that gives pleasant feeling, but also a source of healing. Music as a therapy has developed, supported by many researches conducted by experts in music, education and medicine. The impact of music therapy can be observed in many case studies, showing the positive effects of music to the betterment of human's neuro-behavior, emotional and physical states. Some reasons to use music as a therapy are: toget audioanalgesic response, to focus attention, to reinforce learning, to enhance interpersonal relationships, and to promote mind-body health in the medical staff. The use of music to help patients with non-infectious diseases such as Alzheimer disease, autism, cancer, headache, heart disease and stroke are described along with experiments and case studies on these diseases. However controversies around music therapy occurred. Therefore, more experiments need to be taken in order to clear the controversies and to use music as a therapy in the present and future medical treatment. (Med J Indones 2002; 11: 250-7)
\end{abstract}

Keywords: therapeutic effect, music therapy, Alzheimer, autism, cancer, stroke

Music is defined as the art of organizing sound so as to elicit an aesthetic response in a listener, and consists of vocal and/or instrumental sounds having some degree of rhythm, melody, and harmony. ${ }^{1}$ As stated above, music is an art, which means music is valued for its aesthetic reasons, its beauty. On the other hand, facts and researches have proven that music is not meant only for that reason, but also for other characteristics and effects. Another feature of music is its therapeutic effect to human body, mind and soul. Thus, music is not used solely for recreation and aesthetic reason but also for therapy.

The aims of this paper are to present a general view about music therapy, what is it, its history, and the qualification of music therapists. Experiments around music therapy need to be taken in order to prove the

Third year student Faculty of Medicine University of Indonesia, Jakarta, Indonesia benefit of music as a therapy for certain conditions or illnesses. Therefore, the reasons to use music for therapy are discussed, accompanied with the results from researches and studies on this subject. Several case studies on how music is beneficial for noninfectious diseases such as Alzheimer disease, autism, cancer, headache, heart disease, and stroke are described. Furthermore, some opinions and controversies around music research are presented.

\section{MUSIC THERAPY}

\section{Existence and basic principles of music}

Music was created at almost the same time as the civilizations of humanity and it still exists until now. The whole life times of human being are also surrounded by sounds and music. Starting from inside a mother's womb, an unborn fetus has been exposed to music. Astonishingly, research indicates that learning and remembering of a music can occur 
before birth, at the beginning of the third trimester of pregnancy. ${ }^{2}$ Infants are born with the ability to perceive and process basic musical sounds and patterns. They possess far greater sophisticated abilities for music than previously believed. ${ }^{3}$ During times of growing, sounds and music can not be avoided, and this will always happen until the end of human's life. More over, the brain reveals the fact that humans are all musical, and human's nature is to unconsciously make musical sense of sound. ${ }^{2}$ Therefore, the relationships between human and music are so inseparable. ${ }^{4,5}$

Most people would regard music as something fun and enjoyable; sometimes it gives relaxation to its listeners or motivates them. In addition, there were times when music was a source of inspirations to create great masterpieces. This is the aesthetic characteristics of music.

On the other hand, some of those sounds can be very disturbing, causing great pain and agitation, while some others can be quite soothing and relaxing. Music helps the body and mind to be in one piece so that all the systems and circulation work well. Music is not just for recreation, but apparently it does also have effects to body physiology. ${ }^{6-8}$ Therefore, it is not a surprise if medical world has paid attentions to music as a therapy. Music therapy is not as familiar as some other therapies conducted by therapists and physicians world-wide. On the other hand, since the fact that human is not merely body, but also mind and soul, medical treatment must be performed holistically covering the physiological and psychological aspect. ${ }^{9}$ Music helps physicians in order to perform holistic medical treatment, a treatment to both human's body and mind.

\section{Music Therapy in General}

Music therapy is the skillful use of music and musical elements by an accredited music therapist to promote, maintain and restore mental, physical, emotional and spiritual health. ${ }^{10}$

Music therapy can be applied to wide variety of individual conditions, regardless of age, ability or musical background. It covers many areas such as: acquired brain injury, AIDS, autism/personal disabilities, critical care, development disabilities, emotional traumas, geriatric care, hearing impairments, mental health, neonatal cares, obstetric-gynecology, oncology, pain control, physical disabilities, teens at risk, victim of abuse, visual impairments, and speech and language impairments. Music works as analgesic, stress reducer, and additional therapy within these fields. Basically, music never stands alone as a therapy, but always acts as complementary therapy, and accompanies other medical therapies. ${ }^{10}$

\section{Brief History}

The idea of music as a healing influence that could affect health and behavior is as least as old as the writings of Phytagoras and Plato. ${ }^{11}$ The $20^{\text {th }}$ century usage of music therapy began after World War I and World War II, when community musicians of all types (both amateur and professional), went to Veterans hospitals around the country to play for the thousands of veterans suffering both physical and emotional trauma from the wars. The patients' notable physical and emotional responses to music led the doctors and nurses to request the hiring of musicians by the hospitals. It was soon evident that the hospital musicians need some prior training before entering the facility and so the demand grew for a college curriculum. The first music therapy degree program in the world was founded at Michigan State University in 1944. The American Music Therapy Association was founded in 1998 as a union of the National Association for Music Therapy and the American Association for Music Therapy.

Today, there are a lot of music therapists and institutions that offer music therapy around the world, especially in United States, German, and Holland. This apparently has not been followed by countries in Asia. However, Indonesia has a formal institution that gives music therapy to pregnant women and troubled children.

\section{Music Therapist}

As mentioned above, music therapy deals with a wide range of medical problems. Therefore, music therapists themselves should have good knowledge and skills in medical treatment and therapy. A medical doctor (MD) degree is not necessarily required to be a music therapist, because music therapy has its own undergraduate or graduate degrees. In the USA, a music therapist should have this degree from a university program approved by the American Music Therapy Association (AMTA). It also has to be followed by at least six months of full-time supervised clinical training. Music therapists should also be 
board-certified by the Certification Board for Music Therapy; so they become $M T-B C$ 's (Music Therapist Board Certified) by taking a national exam, and maintain their status through continuing education or re-testing. These terms show that it takes quite a lot to be a music therapist. Therefore, a music therapist must be a well-trained, skillful professional, who masters medical and musical field. ${ }^{10}$

Personality demands to be a music therapist is the possession of self confidence, self-awareness and a realistic perception of his/her strengths and weaknesses. Creativity, spontaneity, full of energy, flexibility and good interpersonal skill are other important attributes. Like doctors and other professionals, music therapists respect the dignity of the people they serve and should conduct themselves according to a code of professional ethics. ${ }^{10}$

Music therapists work with individual and group in an institution, community and private practice settings. ${ }^{10}$

\section{THE REASONS TO USE MUSIC}

It is a fact that medical world nowadays are using music as a therapy, since music is believed to have a relaxing and curative effect to human body, and history has proven that music can be a powerful tool when used professionally. Below are the lists of reasons to use music in medical settings, and other purposes accompanied by several concrete examples of cases and researches concerning the benefit of music therapy.

\section{To get an audio analgesic or sedative respons}

Music can reduce a patients's physiological results of stress or just simply takes the patient's attention from the pain he suffers. ${ }^{12}$ Music has been shown to change patient's brainwave state and stress hormones. There is an increased frequency in a part of the alpha rhythm band, and greater similarities ("coherence") between different regions of the cerebral cortex, most pronounced in the frontal lobes. ${ }^{13}$ Furthermore, right frontal lobe activation is decreased and the secretion of cortisol, a stress hormone, is reduced, both toward normal values. Therefore, music may be able to reverse brain and hormonal states in depression even without mood changes. In another case, music is used in an experiment to find out the effect of soothing music to the arousal states of neonates. The results suggest that soothing music may be a feasible intervention to help newborn demonstrate fewer high arousal states and less liability. ${ }^{14}$ Another study about the sedative/relaxing effect proved that music showed anxiety-reducing, relaxing and beneficial physiological responses. ${ }^{15}$ Although the result of the study concluded that the effect on physiological responses was not significant, hence the therapeutic effect of music to embellish health can not be ignored.

\section{To positively affect biomedical or psychosocial state}

A research on a group of 12 handicapped children aged 3 to 5 was conducted to find out the effect of music to socialization. After 8 months of musical program, once a week, those children showed an increase in their social interaction. Social interaction was increased from $69 \%$ at the beginning to $93 \%$ at the end of the study. The study concluded that listening to music and playing with other children, caused those handicapped children to become more relax and friendly. ${ }^{16}$

\section{To focus attention and/or to structure exercise}

During exercise, music helps to control body movements and coordination. Reducing muscle tension is another therapeutic effect of music. There have been researches on this subject. In a research conducted to a group of college students, they were asked to do some movements while listening to music. Another research was conducted to a group of aerobic students. In both studies, music could improve their movements to pace up, while at the same time improving mental-spiritual mood and motivation. ${ }^{17,18}$ Moreover, music had effects on body hormone, cardiovascular system, and respiration rate. ${ }^{19}$ Listening to New Age, jazz, or classical music for 15 minutes was proven to be able to increase the level of Interleukin-1 (IL-1) in the blood from 12.5\% to $14 \%$; this indicates the increase in immunity. ${ }^{20}$ Moreover, scientists concluded that those music might cause deep, positive emotional experience which unleash hormones that contribute to reduce the factors that cause diseases. Heart beat responds to music variables such as frequency, tempo, volume and beat. ${ }^{19}$ The faster the music, the faster the heart beat, so it is the way around. Slower heart beat creates lower stress and physical tension, calms the mind, and helps the body to repair itself. Like heart beat, respiration rate is also affected by music. ${ }^{21}$ 
Respiration rate will be slower when an individual listens to slow music, and slower respiration rate is better for relaxation, emotional control, and metabolism. Many hospitals set music as a background in the operation room, when operation is done, or when a woman is about to deliver, the music of her own choice is played. The results is not only important for the patient's and doctor's relaxation, but more importantly music is set to focus the attention while relaxing at the same time. A case study of the results of music therapy to pregnant mothers in Austin, Texas reported that more than half of the mother did not need anesthesia while delivering. ${ }^{22}$ Moreover, music gives a relaxing effect to body and mind. It reduces muscle tension by providing an auditory feedback to unleash soothing hormone like endorphin to decrease muscle stress, and resulted in the reduced need of drugs. $17,18,23$

\section{To reinforce learning}

An expert in this field, Howard Gardner of Harvard who was well known for his Multiple Intelligence theory, suggested that musical intelligence (as one of the eight intelligence) influences emotional, spiritual, and cultural development more than any other intelligence. He said that music encouraged the forming of someone's thinking and working patterns that helped them in mathematical, linguistic and visual-spatial learning. ${ }^{24}$ Example of the application is to teach the children of self-care routine or other health principles through music, i.e., composing and listening to music whose lyrics contains health principles.

\section{To provide auditory stimulation/feedback or mask ambient noise}

Music can mask ambient disturbing noise. A research was conducted to observe children's inappropriate behavior in a bus. The research concluded that the number of inappropriate behaviors in the bus were decreased through the use of contingent music. ${ }^{25}$ Another research to a group of 26 males and females observing the effect of music to dental drill noise was conducted. In general, the result showed that music preceding dental drill noise reduced the drill's adverse effects, while the drill preceding music generally enhanced music's positive effects. ${ }^{26}$ In other word, music is an effective tool to mask ambient noise. Therefore, doctors (especially surgeons) and dentists are suggested to set music as a background in their practice room to disguise noises from the running apparatus.

\section{To develop pleasurable and positive interpersonal interactions}

In a music therapy session, there will be discussion, song-writing, singing an instrumental improvisation. These activities is expected to create a trustful and cooperative atmosphere among the patients, members of patients' family and therapists. ${ }^{8}$ Further, this condition can be kept to form a positive interpersonal interaction. After all, an interpersonal interaction is definitely needed, especially between the therapist and the patient. When this happened, there will be a warm and enjoyable meeting, that is substantial to the achievements of the therapy's goals. That music affects interpersonal skill, is discussed by Howard Gardner in his Multiple Intelligence Theory, which also said about the correlation between one intelligence to another. ${ }^{25}$ More over, Gardner's theory was supported by a research on emotionally handicapped middle school students. This research had tried to find out the effect of behavioral music therapy on the generation of interpersonal skills. They found out that a group of children with behavioral music therapy had better interpersonal skill than the control group. ${ }^{27}$

\section{To reduce stress and promote mind-body health in the medical staff}

Music has the power to heal sickness and pain, and to relax the burdened mind of the patients. More than that, music can reduce stress and promote mind-body health in medical staff. Studies to many surgeons have been conducted, and the results showed that the state of anxiety during surgery was decreased when they were listening to music composed by Mozart and Brahms. They also had lower measures of autonomic nervous system activities, lower blood pressure and heart beat when music of their own choice was played. Therefore, they showed better results in accomplishing mental duties faster and more accurate, which finally became a successful surgery. ${ }^{28}$ According to an observation in Cipto Mangunkusumo general national hospital, the use of music in surgery and emergency rooms had brought positive changes not only to the patients, but also to the operators. They admitted that they were in better conditions before, during and after surgery, when music was served as a background, rather than without music. However, this requires further study and research to get more scientific prove in order to be expected world-wide. Still, with all these already-proven experiments, 
setting music as a background in emergency, surgery or in personal practice room is worth to try.

\section{BENEFICIAL EFFECT OF MUSIC ON NON - INFECTIOUS DISEASES}

The beneficial effect of music on six examples of sickness and dysfunction are presented below. However, music therapy not only works on these six diseases, since these are only common cases from the many cases that music therapy concerns with. This article is not intended to explain in detail how music works to help the patients, but just to show an objective fact about the therapeutic effect of music to minimize sickness, heal diseases (temporary or permanent) and rehabilitate.

\section{Alzheimer disease}

A study conducted on Alzheimer patients showed that a group of patients that were listening to an excerpt of Mozart piano sonata enhanced spatial-temporal reasoning, resulting in much better posttest than pretest scores. This showed a significant result compared to the control groups, where no enhancement of scores was seen following control conditions. This finding suggests that music may be used as a tool to investigate functional plasticity in Alzheimer's disease and to better understand the underlying pathophysiology. ${ }^{29}$

Another research supported the claim that music can help Alzheimer patients to have a better social behavior than normal conditions (conditions without music). The research concluded that patients had significantly better social behavior and positive responses to the music treatment which was showed during sessions by increased participation, smiling, eye contact, and verbal feedback expressing pleasure in the activities. The results of the study suggested that individual music activity for Alzheimer's patients may facilitate interaction during the activity and encourage further social contact after that. ${ }^{30}$ Furthermore, other studies and researches encouraged the use of music for the betterment of Alzheimer's patients. ${ }^{31,32}$

Although there has not been any research claiming that music can totally heal Alzheimer's disease, at least many have shown that music can really enhance those patients conditions. Rhythmical interactions, music exercising and listening cause reduction of confusion, and increase in focus and concentration. Moreover, music can enhance the ability to respond verbally and behaviorally, eliminate non-meaning conversations, improve the ability to respond on questions, and improve interpersonal and social relations. ${ }^{33}$

\section{Autism}

Researches on the connection between autism and music therapy can be found in many music therapy journals, since autism is the most frequent disease that is discussed in music therapy journals. ${ }^{34,35}$

In a case report, after long-repeated therapy a girl with autism was cured and she grew up as a normal girl. This famous amazing case, caused the establishment of Georgiana Foundations that used music therapy and sounds to help kids that suffered from autism. ${ }^{\text {cit } 6}$

Autistic children are impaired in noticing and responding to emotional expressions of other people. In a study, to determine whether children with autistic disorders have the ability to detect emotions in stimuli, they are asked to match happy and sad musical selections with simple drawings of happy and sad faces. The autistic children did as well as normal children of the same age and intelligence. The findings show that children suffering from autism have intact abilities to sense emotions in stimuli, and that music is a way to get through to them. ${ }^{36}$

It is important that therapist must create a relaxing and secure atmosphere to communicate with the autistic patients. Music therapy is an alternative method to make this condition. Although generally music is fun and enjoyable, for this kind of therapy, the therapist must choose carefully the type of music, especially when the listeners are hypersensitive. The autistic patients are encouraged to respond to music played during sessions, to initiate their own music, and form a channel of communication with the therapist. ${ }^{37}$

A research done by medical scientists in Wales reported the success of using medical interaction therapy method, i.e. a music oriented medical therapy. A three year-old autistic girl was treated with this method for 2 years, 20 minutes, twice a week. Amazingly, she showed a better psychosocial behavior, emotional state, interpersonal relations, and physiological-kinesthetic movements. Follow up within the next two years revealed that positive changes were still remained. ${ }^{38}$ 


\section{Cancer}

A study reported that music therapy and guided imagery therapy could diminish nausea and vomitting after chemotherapy (cited from Campbell D). ${ }^{6}$ Music therapy can be used to rehabilitate patients after surgery, from increasing motoric ability to selfesteem. $^{6}$

In a study in Ireland Cancer Center, children who received half an hour of music therapy session had improved their immune system. In the treated group, the level of immunoglobulin A (IgA) in subject's saliva was increased, but in contrary, IgA level was decreased in control groups. The study concluded that music could improve our body immunity (cited from Campbell D). ${ }^{6}$ Furthermore, many young cancer patients had better life through music therapy. ${ }^{6}$

\section{Headache}

Around $83 \%$ of the patients who followed special training in music, imagery, and relaxation for two sessions, half an hour each in a week for five weeks, reported that their headache was reduced in the following year, and attacks were lighter and had a shorter period of time. Furthermore, music could prevent terrible headache on those who had followed that music training. A similar study in Poland on 408 patients with severe headache and other nervous disorders reported that those who listened to concert music for 6 months had fewer needs of medication and analgesic compared to the control groups (cited from Campbell D). ${ }^{6}$

\section{Heart disease}

A study reported that there had been a significant decrease of heart beat without clinical arrhythmia (disorders of heart beat) and change to a happier emotional state when coronary-heart disease patients were treated with classical music. The study consisted of 80 heart disease patients. Music relaxation therapy had effectively decrease average heart beat from 100 to 82 beats/minute and systolic blood pressure from 150 to $130 \mathrm{mmHg}$ (cited from Campbell D). ${ }^{6}$

\section{Stroke}

Colorado researches had found that a group of patients with stroke who were given rhythmical auditory stimuli in 30 minutes every day for 3 weeks, showed better improvement of tempo, steps and feet placement compared to the control groups. ${ }^{6,22}$ More over, the researches found out that the effect of the music therapy lasted long. Patients maintained walking patterns they received during the therapy and accurately reproduced their new ways of steps afterwards. Dr. Michael Thaut, a music therapy expert, said that the improvement was caused by the entrainment effect which increased normal mechanism in the damaged-brain due to stroke. Further, in Scotland, a case study on stroke patients, who received music therapy during their treatment reported that those patients had more stable emotion and motivation, and their state of depression and anxiety were decreased, compared to patients who just received conventional treatment (without music therapy).

\section{CONTROVERSIES AROUND MUSIC RESEARCH}

Music therapy is a kind of therapy used in medical field, because of its therapeutic effect on noninfectious diseases. This means that music can reduce stress and pain, heals sickness, and rehabilitates patients with non-infectious diseases. Researches and studies should form a basic foundation for music therapy, so that it may be acceptable and practiced by medical world. Because music therapy is a scientific issue, it requires a systematic, well conducted researches and experiments. Although many researches and studies have been accomplished to prove the efficacy of music as a therapy, controversies concerning the presence of these researches occurred. There are 2 main opinions represented as 'Purist' and 'Utilitarian'.

Accoding to the Purist, music should be studied for its own sake, not because its effects on other aspects of education. ${ }^{39}$ In other words, the Purists showed objection to music researches, and opposed such researches. Purists fight their best to keep music education in schools, and they want to study music and arts only because of the existence of music and arts themselves. They argued that doing music researches to find connections between music and other subjects, would harm the meaning of music itself. In other word, it will give bad effect for music education. ${ }^{40}$

The utilitarian is the opposing group. They agree with the Purists' idea of learning music for its intrinsic merit, but they disagree with the premise that the 
researches' results are bad for music education. They believe that music should not be excluded from research on any aspects of behavior it touches. In short, music is a sufficientlu important subject to get the attention and efforts of both arts workers and science workers. Basically, if music researches and studies showed that music was beneficial to other aspects of human life, they should not be prohibited. ${ }^{39,40}$

The controversies can go on continuously, since each side has their own arguments and principles. They can either have unending debates over this matter or they can sit together and discuss as rational and scientific people by willingly listen to others opinion in order to have serious and extended dialogues, to set and achieve common goals to this issue. ${ }^{39,40}$ In addition, medical scientists and doctors must always remember the Helsinki declaration which stated that the patients' health is every doctor's greatest concern, therefore, a rational and open-minded discussion is preferable.

\section{CONCLUSION}

Almost all people regard music as harmonious, wellcrafted melodies that is fun and enjoyable. Music can affect mood and emotions of its listeners. More than that, music also gives therapeutic effect that will enhance the condition of human neuro-behavior, emotion and physiological states, when used properly by professional and skillful therapist. Music can act as complementary medicine, to heal/reduce noninfectious diseases, and to rehabilitate. Many researches have proven the efficacy of music to be used as a therapy. Still, controversies on these researches occurred. However, doctors and medical scientists must always remember the Helsinki declaration, that the health of the patient is every doctor's greatest concern. Therefore, a rational and open-minded discussion is needed to solve the controversies. Further researches and experiments are needed in the future to support the existence and development of music therapy. It is better not to reject music as a therapy totally or applying it uncritically, instead, all medical actions should be based on scientific matters and theories.

\section{SUGGESTION}

Below are some suggestions about music therapy implementation and research in Indonesia. These suggestions are intended to gain more knowledge about music therapy and to improve the development of music therapy in Indonesia.

1. Practical applications of music can be done in many places to get therapeutic effects. For example, by playing music as a background in classrooms, offices, surgery and emergency rooms, private practice chambers, and other places.

2. Support the founding of music therapy institutions that provide music therapy as a complementary medicine to patients, and act as the center of music therapy research and development.

3. Encourage more music therapy researches. Collaboration of researchers that included experts in music, psychology, psychiatry, neurology, and other therapists in medical fields in needed.

4. Conduct experiments to find Indonesian traditional music that can be used for music therapy or to find the therapeutic effects of those music.

5. Initiate a music therapy program by introducing it as a subject in one or several universities. This program, like other majors, must also have its own undergraduate and graduate degree, and should be certified by AMTA. As a result, we can enhance relationships with many international music therapy institutions, which in turn can give more knowledge to the betterment of music therapy progress in Indonesia.

\section{Acknowledgement}

The author would like to thank Prof. Dr. Arjatmo Tjokronegoro, Drs. Lukas Mangindaan, M Sopiyudin, Egi E. Manuputty, Trevino A. Pakassi, and Grace Wangge, for all their help in writing this article.

\section{REFERENCES}

1. The American Heritage Dictionary. New York: Dell Publishing: 1983.p.451.

2. Hepper PG. The musical foetus. Irish journal of Psychology 1991;12:95-107.

3. Saffran JR, Loman MM, Robertson RRW. Infant memory of musical experiences. Cognition 2000:77:B15-23.

4. Szemedra L, Bacharach DW. Effect of music on perceived exertion, plasma lactal, norepinephrine and cardiovascular hemodynamics during treadmill running. Int J Sports Med 1998;19:32-7.

5. Weinberger NM. What the brain tells us about music: amazing facts and astonishing implication revealed. MuSICA Research Notes [serial online] 2000 [cited 
2002 Jun 5];7(3):[3 screens]. Available from: http://www.musica.uci.edu/mrn/V713F00.html.

6. Campbell D. Efek Mozart. Jakarta: PT Gramedia Pustaka Utama, 2001

7. Weinberger NM. Lessons of the music womb. MuSICA Research Notes [serial online] 1999 [cited 2002 Jun 3];6(1):[3 screens]. Available from: http://www.musica.uci.edu/ mrn/V611W99.html.

8. Stocking J. Students music scientists. MuSICA Research Notes [serial online] 2000[cited 2002 Jun 5];7(2)[3 screens]. Available from: http://www.musica.uci.edu/ mrn/V712S00.html.

9. Weinberger NM. The musical hormone. (Editor's note). MuSICA Research Notes [serial online] 1997 [cited 2002 Jun 3];6(2):[3 screens]. Available from: http://www.musica.uci.edu/mrn/v511w98.html

10. Proceeding of General Meeting of Canadian Association of Music Therapy (CAMT). Vancouver, British Colombia, 1994 May $6^{\text {th }}$. [cited 2002 Jun 3]:[ 3 screens ]. Available from http://www.musictherapy.ca/

11. Storr A. Instrumental to the brain. $\mathrm{Br}$ Med $\mathrm{J}$ 1996;312:1308.

12. Field T. Music alleviates and hormonal abnormalities in depressed teens. J Adolesc 1998;33:109-16.

13. Malyarenko TN. Music alters children's brainwaves. Human Physiol 1996;22:70-81.

14. Kaminski J, Hall W. The effect of soothing music on neonatal behavior in the hospital neborn nursery. Neonatal Netw 1996;15:45-54.

15. Davis WB, Michael HT. The influence of preferred relaxing music on measure of state anxiety, relaxation, and physiological responses. J Music Ther 1989; 26(4):168-87.

16. Humpal M. The effect of an integrated early childhood music program in social interaction among children with handicaps and their typical peers. J Music Ther 1991;28:161-77.

17. Thaut M, Schleiffers S, David W. analysis of WMG motor task under the influence of auditory rhythm. J Music Ther 1991;28:64-88.

18. Gfeller K. Musical components and styles preferred by young adults for aerobic fitness activities. J Music Ther 1988;25:28-43.

19. Iwanaga M. Relationship between heart rate and preference for tempo music. Percept Mot Skills 1995;81:435-40.

20. Bartlett D, Kaufman D, Smeltekop R. The effects of music listening and perceived sensory experiences on the immune system as measured by Interleukin 1 and Cortisol. J Music Ther 1993;30:194-209.

21. Barzum J, editor. Pleasures of music. Chicago: University of Chicago Press, 1977.

22. Marwick C. leaving concert hall for clinic, therapists now test music's charm. J Am Med Assoc 1995;265(4):267-8.

23. Droh, Spintge. Anxiety, pain, and music in Anesthesia. Basel: Roche, 1983.
24. Gardner H. The frames of mind. New York: basic Books, 1983.

25. McCarthy BC, Colleen M, Shelia VR. The effect of contingent background music on inappropriate bus behavior. J Music Ther 1998;35(3):150-6.

26. Standley JM. The effect of vibrotactile and auditory stimuli on perception of comfort, heart rate, and peripheral finger temperature. J Music Ther 1991;28(3):120-34.

27. Eidson Jr, Carl E. the effect of behavioral music therapy on the generalization of interpersonal skills from sessions to the classroom by emotionally handicapped middle school students. J Music Ther 1989;26(4):206-21.

28. Allen K, Blascavich J. Effects of music on cardiovascular reactivity among surgeons. J Am Med Assoc 1994; 272:882-4

29. Johnson JK, Cotman CW, Tasuki CS. Enhancement of spatial-temporal reasoning after a Mozart condition in Alzheimer's disease: A case study. Neurol Res 1998;20:666-72.

30. Pollack NJ, Kevan HN. The effect of music participation on the social behavior of Alzheimer's disease patients. J Music Ther 1992;29(1):54-67.

31. Brotons M, Patricia KPC. The effects of music therapy intervention on agitation behavior of Alzheimer's disease patients. J Music Ther 1996;33(1):2-18.

32. Groene II R. The effect of therapist and activity characteristics on the purposeful responses of probable Alzheimer's disease participants. J Music Therapy 1999;36(2):119-36.

33. Prickett CA, Moore RS. The use of music to aid memory of Alzheimer's patients. J Music Ther 1991;28:101-10.

34. Edgerton, Cindy L. The effect of improvisational music therapy on the communicative behavior of Autistic children. J Music Ther 1994;31(1):31-62.

35. Buday EM. The effects of signed and spoken words taught with music on sign and speech imitation by children with Autism. J Music Ther 1996;33(3):189-202.

36. Heaton P. Music "gets through" Autistic children. Psychological Medicine 1999;19:1405-10.

37. Carlton S. The other side of Autism. Cornwall: The Self Publishing Association, 1993.

38. Wimpory D, Chadwick P, Nash S. Brief report: Musical interaction therapy for children with Autism: An evaluative case study with two-year follow uo. J Autism Dev Disord 1995;25:541-9.

39. Weinberger NM. Purists and Utilitarian. MuSICA Research Notes [serial online] 1996 [cited 2002 Jun 3];3(2):[3 screens]. Available from http://www.musica.uci.edu/v312F96.html\#Purists.

40. Weinberger NM. Responding to attacks on music research. MuSICA Research Notes [serial online] 1999 [cited 2002 Jun 3]:6(2):[3 screens]. Available from http://www.musica.uci.edu/v612S99.html\#attacks. 